\title{
The Buffalo Hills Kimberlite Province, North-central Alberta, Canada
}

\author{
Carlson, S.M. ${ }^{1}$, Hillier, W.D. ${ }^{1}$, Hood, C.T. ${ }^{1}$, Pryde, R.P. ${ }^{2}$, and Skelton, D.N. ${ }^{1}$
}

1. Ashton Mining of Canada Inc., Unit 123 - 930 West $1^{\text {st }}$ Street, North Vancouver, BC V7P 3N4, Canada

2. Alberta Energy Co. Ltd., AEC West New Ventures, 3700, $707-8^{\text {th }}$ Ave. SW, Calgary, AB T2P 1H5, Canada

The Buffalo Hills kimberlite province is located in north-central Alberta, approximately $360 \mathrm{~km}$ northwest of the city of Edmonton, near the hamlet of Red Earth Creek. The province is named after the Buffalo Head Hills, a northerly-trending physiographic feature of moderate relief bounded to the west by the Peace River drainage and to the east by the Loon and Wabasca River drainages. The Buffalo Hills kimberlites represent a new and heretofore undocumented Canadian kimberlite province; prior to this discovery in 1997, the only kimberlites known in Alberta were two pipes of "possible kimberlite" located at Mountain Lake, $180 \mathrm{~km}$ to the southwest (Leckie et al., 1997).

Kimberlites in the Buffalo Hills province are underlain by the Buffalo Head Terrane, an Early Proterozoic tectonostratigraphic designation for the Precambrian basement in this area. Evidence from Sm-Nd studies suggests that the Buffalo Head Terrane may include a significant component of remobilized Archean material. Various degrees of mixing of evolved and juvenile material resulted in the formation of 2.32 to $2.0 \mathrm{Ga}$ crust, and a subsequent thermal-magmatic event between 1.9 and 2.0 $\mathrm{Ga}$ reset the zircon crystallization ages (Villeneuve et al., 1993). The Buffalo Head Terrane consists predominantly of high-grade metamorphic rocks; these are not exposed at surface, but are covered by $\mathrm{a} \sim 1600 \mathrm{~m}$ thick sequence of Devonian and Cretaceous sedimentary rocks.

The Buffalo Hills kimberlites were first detected on a fixed-wing aeromagnetic survey conducted for oil and gas exploration. The resultant high-resolution data were acquired by Alberta Energy Company Ltd. in 1995 to assist in the interpretation of the Precambrian basement structural grain. The dominant features defined by the survey were long-wavelength, but several shallow, highfrequency anomalies were also recognized. Investigation of pre-existing seismic profiles in the vicinity of these anomalies revealed very strong diffractions and extensive data gaps, where actual data had been removed from the final stacked and processed versions since these data were considered to be spurious. The unusual signatures suggested that the aeromagnetic anomalies were possibly the result of disruptive volcanic intrusives. These geophysical data were brought to the attention of Ashton Mining of Canada Inc. in October of 1996, and an option agreement was signed by Ashton Mining of Canada Inc., Pure Gold Resources Inc. and Alberta Energy Company Ltd. to investigate these anomalies.

To date, 15 kimberlites have been discovered in the province, with inferred sizes ranging from $<1$ to $\sim 45$ ha. Some pipes are covered by variable thicknesses of glacial overburden up to $90 \mathrm{~m}$ deep. Several kimberlites outcrop, including the spectacular example of kimberlite K5 that forms a hill some $60 \mathrm{~m}$ high. Deep seismic profiles suggest that many kimberlites in the province exhibit distinct pipe-like morphologies, with initial pipe flaring apparently beginning at the boundary between Precambrian and Phanerozoic sequences. U-Pb dating of perovskite suggests that the Buffalo Hills kimberlites were emplaced between $86 \pm 3$ and $88 \pm 5 \mathrm{Ma}$.

Initial petrological studies of the Buffalo Hills kimberlites indicate that all material recovered to date is crater facies. A diatreme-facies component has not as yet been identified in drill core from depths of up to $200 \mathrm{~m}$. Volcanic stratigraphy is dominated by lapilli-bearing olivine crystal tuffs, 
occasionally with well-defined, generally normally-graded beds varying from coarse ash to coarse crystal. Juvenile lapilli-rich beds and rare autoliths have also been noted, particularly in kimberlites $\mathrm{K} 6, \mathrm{~K} 91$, and $\mathrm{K} 14$, and minor interfingering sedimentary beds have been identified in drill holes from several pipes. Lapilli are generally spherical or amoeboid in form, with the former frequently nucleated on olivine macrocrysts; vesicles are a common feature of many amoeboid lapilli. Crustal xenoliths are typically shales of the Shaftesbury formation and commonly display margins embayed by olivine grains, suggesting an un- or semi-lithified state (for the host rock) during kimberlite emplacement. In several pipes, silica alteration erases primary textures in the uppermost parts of the sequence, while bitumen is abundant as fracture infillings throughout some of the kimberlites.

Petrographic examination of the macrocryst mineralogy of the Buffalo Hills kimberlites reveals a preponderance of olivine, which occurs as ovoid grains up to one centimeter in length, and as smaller, generally subhedral grains. Olivines are typically pseudomorphed by magnetite and calcite at higher levels, ranging through to serpentine, calcite, and pyrite at depth and into fresh olivine in the most unaltered material. Mica is an occasional constituent of the macrocryst assemblage, appearing as laths up to $5 \mathrm{~mm}$ in length. An unusual greenish mineral (possibly antigorite plus chlorite) is abundant in some pipes, occurring as platy, sometimes vermiform grains up to $15 \mathrm{~mm}$ in length. Microphenocrysts of mica, perovskite, atoll-textured spinel, and apatite are also present. Groundmass mineralogy is generally a fine-grained, sometimes segregational assemblage of serpentine, dolomite, calcite, and chlorite. Pyrite, Ni-sulfide, rutile, and ilmenite are frequent microcrystalline accessory phases.

The Buffalo Hills pipes are considered to be group I kimberlites. Spinel microphenocrysts from several pipes have been analyzed and appear to exhibit magmatic trend 1, the compositional trend associated with group I kimberlites (Mitchell, 1995). Microphenocrysts of mica show evolution from phlogopite towards aluminous phlogopite, thus plotting along the kimberlite trend on $\mathrm{Al}_{2} \mathrm{O}_{3}$ wt $\%$ vs. $\mathrm{TiO}_{2}$ wt $\%$ diagrams (Mitchell, 1995). Some of the more aluminous micas display barium enrichment, with up to $2.9 \mathrm{wt} \% \mathrm{BaO}$. Additional support for the classification of these rocks as kimberlites is provided by the presence of a classic kimberlitic indicator mineral suite, including diamond, and the lack of any atypical typomorphic minerals. Attempts to classify these rocks via whole-rock analysis have met with limited success; this approach does not appear to be well-suited to the crater-facies rocks recovered to date.

The full suite of kimberlitic indicator minerals is present in the Buffalo Hills pipes. Minerals derived from mantle peridotites and pyroxenites include olivine (forsterite), chromian pyrope, calcic knorringite, chromian diopside and augite, enstatite and various chromian spinels, principally aluminous magnesian chromite. The chromian garnet compositions suggest derivation from lherzolitic rocks, with harzburgitic, wehrlitic and probable websteritic rock types less represented. Whereas the kimberlites in the southern part of the province contain only rare subcalcic (G10) garnets, the northern pipes do contain a significant number of G10s, including some strongly metameric varieties with exceptionally high chromium contents of up to 17.8 wt $\% \mathrm{Cr}_{2} \mathrm{O}_{3}$. Aluminous magnesian chromites generally contain between $30 \mathrm{wt} \%$ and $62 \mathrm{wt} \% \mathrm{Cr}_{2} \mathrm{O}_{3}$; the number of grains with diamond inclusion chemistry is highly variable from one pipe to the next, however no significant trends have been noted across the province. Xenocrysts of eclogitic derivation are less common in the kimberlites and have not been extensively investigated. 
Additional mineral species recovered from heavy mineral concentrates include diamond, chromian corundum, chromian amphibole, spinel (Mg-Al), magnesian ilmenite, titanian pyrope, almandine, grossular, and zircon. These minerals are presumably derived from both mantle and lower crustal source rocks. Of particular interest is magnesian ilmenite, a mineral that to date has only been recovered in trace quantities from kimberlite $\mathrm{K} 2$ in the southern part of the province; kimberlites north of K2 appear to lack magnesian ilmenite altogether. Ilmenite from K2 contains substantial niobium, ranging between $1.0 \mathrm{wt} \%$ and $3.0 \mathrm{wt} \% \mathrm{Nb}_{2} \mathrm{O}_{5}$.

The mantle-derived xenolith population includes peridotitic, pyroxenitic, eclogitic and corundumspinel-bearing lithologies, with abundances highest in kimberlite K14. Xenoliths of peridotitic classification can be divided into several subgroups based on mineralogy and mineral chemistry, including (in decreasing order of abundance) lherzolite, wehrlite and harzburgite parageneses. Textures vary from coarse-granular through coarse-tabular and porphyroclastic-sheared, to much rarer fluidal styles. Pyroxenites and eclogites are less abundant; graphite has been noted as an accessory phase in the latter. Corundum-spinel xenoliths (consisting of dark green spinel and red chromian corundum in a calcite-chlorite matrix) are unusual constituents of a few pipes.

Evaluation of the diamond potential of the Buffalo Hills kimberlites is still in the preliminary testing stages. Diamonds have been recovered from small $(36-91 \mathrm{~kg})$ core and trench samples of all pipes except $\mathrm{K} 4 \mathrm{C}, \mathrm{K} 7 \mathrm{~A}$, and $\mathrm{K} 7 \mathrm{C}$. The diamond microcrysts $(<0.5 \mathrm{~mm})$ are predominantly sharp-edged octahedra, macles, and octahedral aggregates. By contrast, the diamond macrocryst $(>0.5 \mathrm{~mm})$ population is dominated by tetrahexahedra and resorbed fragments, with subordinate octahedra and very rare cubes. The largest diamond found to date is a $0.6 \mathrm{ct}$ octahedral aggregate, recovered from a 27.4 tonne mini-bulk sample of kimberlite K14.

The Buffalo Hills kimberlite province is a significant discovery in the history of worldwide kimberlite exploration. Preliminary high-resolution aeromagnetic surveys suggest that the 15 kimberlites discovered to date may be only a minor part of a large, multi-field province that could prove to contain numerous additional kimberlite pipes. The large size of some of these kimberlites coupled with broadly favorable indicator mineral chemistry and the presence of diamond indicate that the Buffalo Hills province may have the potential to host economic diamond deposits.

The authors wish to thank Dr. Barbara Scott Smith and Dr. Roger H. Mitchell for their contributions to the understanding of the petrology of the Buffalo Hills kimberlites.

\section{References}

Leckie, D.A., and Kjarsgaard, B., et al., 1997, Geology of a late Cretaceous possible kimberlite at Mountain Lake, Alberta-chemistry, petrology, indicator minerals, aeromagnetic signature, age, stratigraphic position and setting: GSC Open File Report 3441, 202 p.

Mitchell, R.H., 1995, Kimberlites, orangeites, and related rocks: Plenum Press, 410 p.

Villeneuve, M.E., Ross, G.M., Thériault, R.J., Miles, W., Parrish, R.R., and Broome, J., 1993, Tectonic subdivision and $\mathrm{U}-\mathrm{Pb}$ geochronology of the crystalline basement of the Alberta basin, western Canada: GSC Bulletin 447, 85 p. 